Images in...

\title{
Paradoxical digital ischaemia
}

\author{
N Shahi, R Nair \\ Sheffield Vascular Institute, Northern General Hospital, Sheffield Teaching Hospitals NHS Foundation Trust, Sheffield, UK
}

Correspondence to N Shahi, dr_navi9@yahoo.co.uk

\section{DESCRIPTION}

A young lady presented with an 8-day history of cramping pain in her right hand with ischaemic index and middle fingers (figure 1). Examination revealed no palpable pulses in the right upper limb, no aneurysms, thrills or audible heart murmurs. An electrocardiogram was normal. An arterial duplex scan showed turbulent waveforms in the subclavian artery and triphasic waveforms distally.

Arch angiography showed an aberrant right subclavian artery (figure 2) and small thrombi occluding the digital vessels of the index and middle fingers. She developed progressive lower-limb oedema and a venous duplex confirmed a non-occlusive thrombus in the right iliofemoral veins extending to the inferior vena cava.

A trans-thoracic echo showed poor views of the mitral and tricuspid valves and no obvious thrombus. However, a trans-oesophageal echo showed a patent foramen ovale
(PFO) with bi-directional shunting, visible without having to perform a valsalva manoeuvre (video 1 ).

Video 1 Video of the trans-oesophageal echo showing the patent foramen ovale. 10.1136/bcr.10.2009.2413v1

The digital ischaemia was ascribed to a paradoxical embolus via a $\mathrm{PFO}$.

Paradoxical embolism is a rare cause of acute limb ischaemia. ${ }^{1}$ Probe patient PFO occurs in approximately $30 \%$ of the population, but larger defects able to admit the tip of a pencil occur in $7 \% .^{2}$

Trans-esophageal echo has a higher sensitivity (79\%), specificity $(75 \%)$ and positive predictive value $(65 \%)$ than trans-thoracic echo $(7 \%, 100 \%$ and $50 \%$, respectively) in detecting a $\mathrm{PFO} .^{3}$

This highlights not only the need for a diagnosis in patients with acute ischaemia and no obvious source of

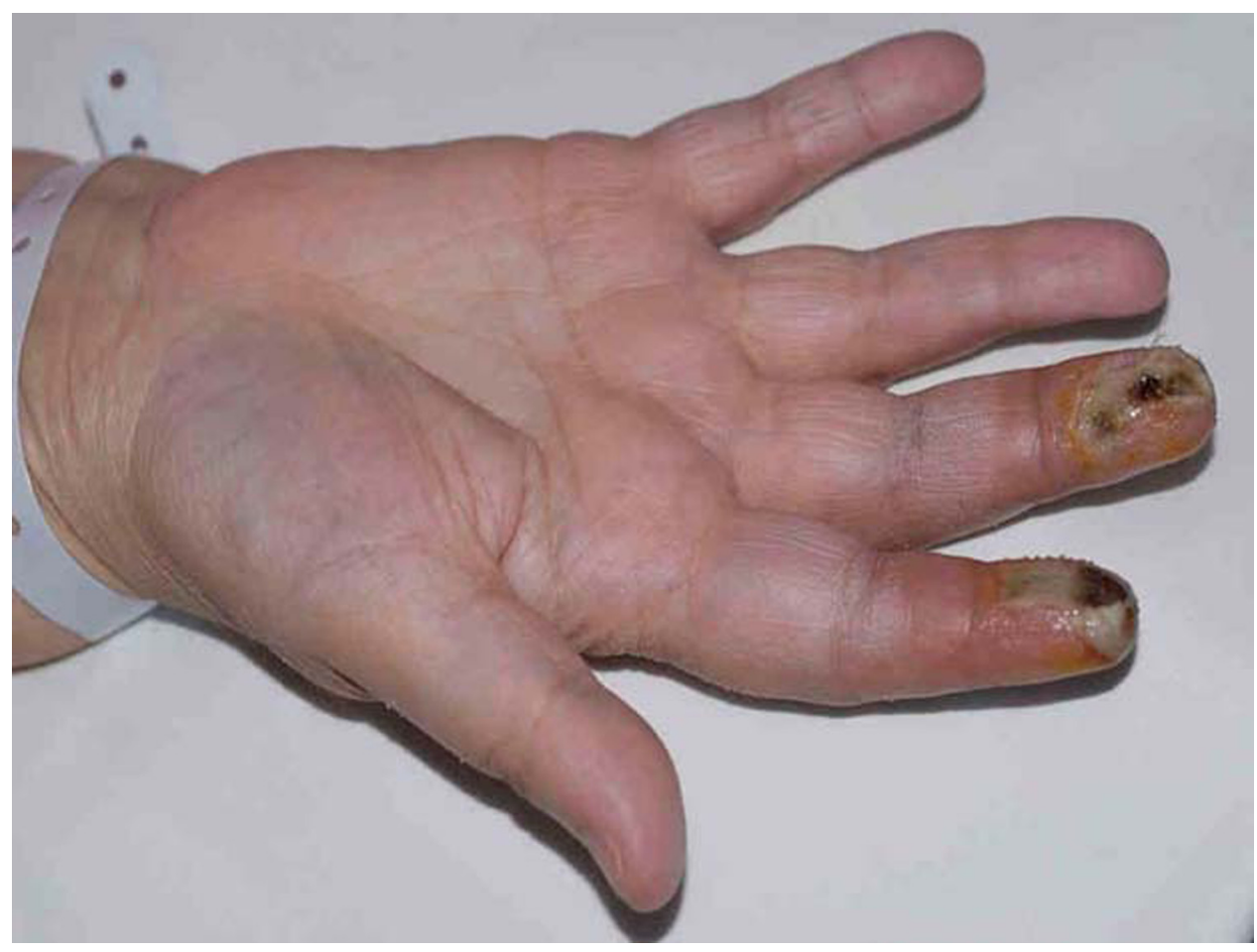

Figure 1 Digital ischaemia with secondary pulp space abscesses. 


\section{BMJ Case Reports}

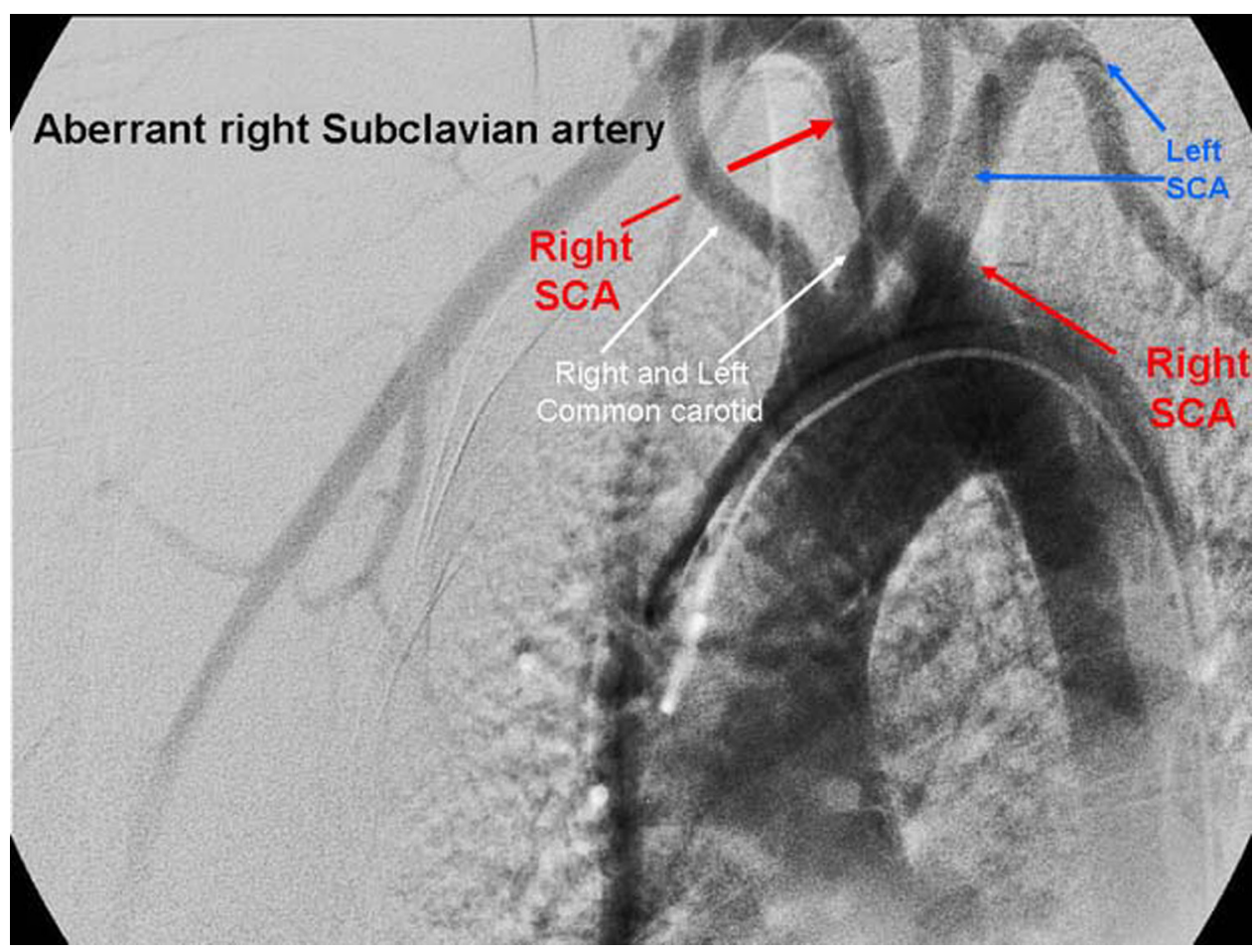

Figure 2 Aberrant right subclavian artery.

emboli, but also the importance of trans-oesophageal echo in detecting $\mathrm{PFO}$.

\section{Competing interests None.}

Patient consent Obtained
2. Hagen PT, Scholz DG, Edwards WD. Incidence and size of patent foramen ovale during the first 10 decades of life: an autopsy study of 965 normal hearts. Mayo Clin Proc 1984:59:17-20.

3. Belkin RN, Pollack BD, Ruggiero ML, et al. Comparison of transesophageal and transthoracic echocardiography with contrast and color flow Doppler in the detection of patent foramen ovale. Am Heart J 1994;128:520-5.

\section{REFERENCES}

1. Meister SG, Grossman W, Dexter L, et al. Paradoxical embolism. Diagnosis during life. Am J Med 1972;53:292-8.

\footnotetext{
This pdf has been created automatically from the final edited text and images.

Copyright 2010 BMJ Publishing Group. All rights reserved. For permission to reuse any of this content visit http://group.bmj.com/group/rights-licensing/permissions.

BMJ Case Report Fellows may re-use this article for personal use and teaching without any further permission.

Please cite this article as follows (you will need to access the article online to obtain the date of publication).

Shahi N, Nair R. Paradoxical digital ischaemia. BMJ Case Reports 2010;10.1136/bcr.10.2009.2413, date of publication

Become a Fellow of BMJ Case Reports today and you can:

- Submit as many cases as you like

- Enjoy fast sympathetic peer review and rapid publication of accepted articles

- Access all the published articles

- Re-use any of the published material for personal use and teaching without further permission

For information on Institutional Fellowships contact consortiasales@bmjgroup.com

Visit casereports.bmj.com for more articles like this and to become a Fellow
} 